\title{
Intensity of the continuous feed mixing process in the mixer
}

\author{
Eshpulat Eshdavlatov*, Alisher Suyunov, and Islom Choriyev \\ Karshi Engineering Economic Institute, Karshi, Uzbekistan
}

\begin{abstract}
The physical basis of the mixture formation is analyzed. The study aims to increase the intensity of the process of continuous mixing of feed in the mixer. The basic principles and methods of classical mechanics, mathematical analysis, and statistics were used in this study. The design of the mixer cover in the form of a three-sided box is justified, which eliminates additional resistance to the rotation of the screw due to the impact of the feed masses reflected from the cover. When using a lid in the form of a three-sided box, the mixing quality improves by $4-5 \%$ and reaches $93 \%$ or more at a capacity of $15 \mathrm{t} / \mathrm{h}$. It is established that the optimal angle of inclination of the reflecting plane of the mixing chamber cover is $31-35^{\circ}$ with a screw diameter of $400 \mathrm{~mm}$, the height of the reflecting plane from the screw axis of $350 \mathrm{~mm}$, and a rotation speed of $36.61 \mathrm{~s}^{-1}$. The following indicators of the mixer were determined: the productivity that ensures the mixing quality of more than $90 \%$ when mixing green mass and silage with mixed feed $-19 \mathrm{t} / \mathrm{h}$, crushed feed root crops with mixed feed-23 $\mathrm{t} / \mathrm{h}$, the speed of the screw $-36.61 \mathrm{~s}^{-1}$.
\end{abstract}

\section{Introduction}

Among the complex measures aimed at the intensification of animal husbandry, one of the central places is occupied by the production and preparation of feed. At the same time, special importance is attached to the provision of farms with their own feed, improving their quality, using them most effectively with the least labor and money costs. Therefore, in Uzbekistan, research works are being conducted aimed at developing new technologies and technical means for tillage [1-23], sowing and harvesting [3, 10, 11, 19, 20] of forage crops and their primary processing [22].

The final operation of the preparation of feed mixtures is mixing the components, which is carried out in special devices-batch or continuous mixers.

There are two main requirements for feed mixing lines. They must: ensure the ratio of components by weight in the finished mixture specified by the recipe with deviations not exceeding the established tolerances; redistribute the particles of the mixed components so that the indicator of the unevenness of their distribution is within the zootechnical requirements.

The study aims to increase the intensity of the process of continuous mixing of feed.

\footnotetext{
* Corresponding author: eeshpulat@umail.uz
} 


\section{Methods}

The basic principles and methods of classical mechanics, mathematical analysis, and statistics were used in this study. In the theory of mixing, an important place is occupied by questions aimed at studying the mechanism of mixture formation itself, which proceeds differently depending on the design of the working bodies of the mixers. Of great interest are the works of E.Raskatova and E.Kolychev [24-25], in which an attempt is made to analyze the physical basis of mixing. In these works, it is concluded that along with mixing, there is an inverse process - separation (segregation), and therefore the equation of the kinetics of the process is presented in the form

$$
k=f_{1}(t)-f_{2}(t)
$$

where $k$ is the mass uniformity index; $f_{1}(t), f_{2}(t)$ are functions that characterize the forward and reverse processes.

In this case, dynamic equilibrium occurs when the speed of the main and reverse processes are aligned in absolute value and continue to remain equal in the future, that is,

$$
f_{1}(t)=-f_{2}(t)
$$

In the work of P.Zhevlakov [26], the kinematics of mixing is considered as a change in the concentration of the $C$ component under study, and the dependence of the mixing process speed on the change in $C$ per unit of time is justified, that is,

$$
v=d C_{i} / d t
$$

However, P.Zhelvakov states that the absolute mixing rate is equal to the algebraic sum of the speeds of the forward and reverse processes, and not their difference, that is,

$$
f(t)=f_{n}(t)+f_{0}(t)
$$

The equation given by E.Raskatova and E.Klyuchevoy [24-25] will be correct only in the case of diffusion mixing since after dynamic equilibrium, there is an inverse process, that is, separation.

For other types of the mixing process, the formula given by P.Zhevlakov is completely valid, i.e., the forward and reverse processes occur simultaneously.

Analyzing the above works, it can be noted that the acceleration of the mixing process, that is, the rate of onset of dynamic equilibrium, depends on the acceleration of the intensity of the forward and reverse processes. This is true for all types of mixing, except for diffusion.

Increasing the intensity of the forward and reverse processes can be achieved in different ways, namely by education in the mass of the layer sliding over each other planes (mix shift); move groups of particles from one position to another (diffusion mix); move groups of particles from one position to another (convective mixing); redistribution of individual material particles in the layer (diffusion mix); scattering of a single particle under the influence of their impact or blows on the walls of the evaporator (drum mix) [2427].

Depending on the type of mixer and the structural and mechanical properties of the feed components, one or more of these processes will prevail.

Thus, it can be concluded that the more these processes take place during mixing, 
the more the mixing intensity increases.

Participation in the mixing process of elementary processes depends on many factors, which can be divided into the following groups [24-27]:

1. The physical properties of the blend components: the regular geometrical shape of the particles, their uniformity, the ratio of the geometric dimensions of the particles of the feed components, fractional properties, defined by the coefficients of external and internal friction, bulk density in free of compaction, the porosity of the mixture components, moisture content, particle size distribution, uniform grinding of components and others.

2. Design parameters of mixers: the form of flat and three-dimensional working bodies of the mixer, their combination and geometric dimensions; linear and circular dimensions and the ratio of the step working bodies and their elements; the ratio of length and diameter of the working bodies and the mixing chamber; the dimensions of the radial and axial clearances of the working area of the faucet; fill factor of the volume of the working chamber of mixing; the state of the surface and the material of the working bodies and camera mixing; the angle of attack of the blades of the screw and lift planes and elements of the working bodies; the number and placement options of the working bodies; the design of the feeding and discharge device; the conditions and method of feeding the material into and out of the mixing working area.

3. The kinematic parameters of the working bodies and the treated mixture, comprising: a portable, relative, and absolute velocity and acceleration of the working bodies, their elements, and representative volume of mixture components transported in the radial and axial directions of the working area of the mixer, the shear rate at the interface of the components of the mixture in the volume of the working area of the machine.

4. Power parameters including 1) the movement is defined by the transmission of pressure in the granular medium, the centrifugal forces in the friction of particles connection with the working bodies, particle mass, the force for a screw displacement, and the circulation flow of the mixture; 2) the drag force determined by the factors of external and internal friction of the material on the moving and stationary bodies; resistance power depending on the velocity of movement of particles of compounds for high-speed mixers; 3 ) passive force reactions from working bodies.

The variety of these parameters that affect the mixing process determines the need for a separate and comprehensive study of their impact on the mixing process and its preparation.

One of the factors affecting the mixing process is the shape of the mixing chamber. This is especially true for mixers with a stirrer working body.

Mixing chambers of a mixer with a stirrer working body can be divided into two main groups: without free space above the working body for slow-speed mixers and with free space for high-speed mixers.

1. The analysis of the structure of the mixing chambers can make the following conclusions: when the supply of the camera mixing flat caps, planted forage when they hit the lid dismembered, but reflected from the lid creates additional resistance to the rotation of the working body; a curved cover shape eliminates the additional forces of resistance, impairs the mixing conditions; the presence of space between the lid and the working body of the mixer provides the chaotic conditions of mixing; it is advisable to provide the mixing chamber with a lid of such a shape that would ensure the dismemberment and such a movement of the thrown feed mass that the feed return zone to the working body after reflection from the mixer cover does not coincide with the ejection zone.

\section{Results and Discussion}


The presence in the proposed design of the mixer of a multi-stroke screw with turns alternately interrupted by the value of one step and free space in the upper part of the mixer body contributes to the tossing of feed particles and, accordingly, to the elongation of the trajectory of its movement [28-33].

To select a rational form of the mixing chamber, preliminary experimental studies were carried out on a specially created installation.

The experimental setup (Fig.1) is based on a mixer. It consists of a feed conveyor with a length of $6.5 \mathrm{~m}$ with a belt speed of $0.321 \mathrm{~m} / \mathrm{s}$, a mixer with a working chamber length of 3.5 $\mathrm{m}$, an unloading conveyor with a length of $3.5 \mathrm{~m}$ and a paddle-type dispenser for entering the control component.

The dispenser is installed above the feed conveyor in the feed loading area of the mixer. The drive is carried out from the gear motor conveyor; the feed dispenser is regulated by the movement of the vane rotor along the axis of rotation, the rotor speed constant.

Cells for sampling are installed along the entire length of the discharge conveyor belt with a step of $200 \mathrm{~mm}$. The cells are made of sheet steel with a size of 50x50x200 mm (see Fig.1).

The speed of the mixer screw is regulated by five replaceable sprockets - two for the gear motor $\left(Z_{1}=25, Z_{2}=32\right)$ and three for the mixer shaft $\left(Z_{3}=22, Z_{4}=25, Z_{5}=28\right)$.

The experimental setup is prepared as follows. First, the crushed feed components are weighted according to the specified mixer capacity, taking into account the speed of the feed conveyor belt. Then they are laid in layers on the loading conveyor.

Control component (barley grain, painted nitro enamels in red) is poured into the hopper of the dispenser. Previously, the dispenser is adjusted to the specified feed, respectively, with the feed components.

The installation works as follows. The electric drives of the mixer and the sluice gates are switched on, then the feed and discharge conveyors are switched on. Together with the control component, the feed components are fed through the sluice gate into the mixer. The finished feed mixture is unloaded onto an unloading conveyor with cells for sampling.

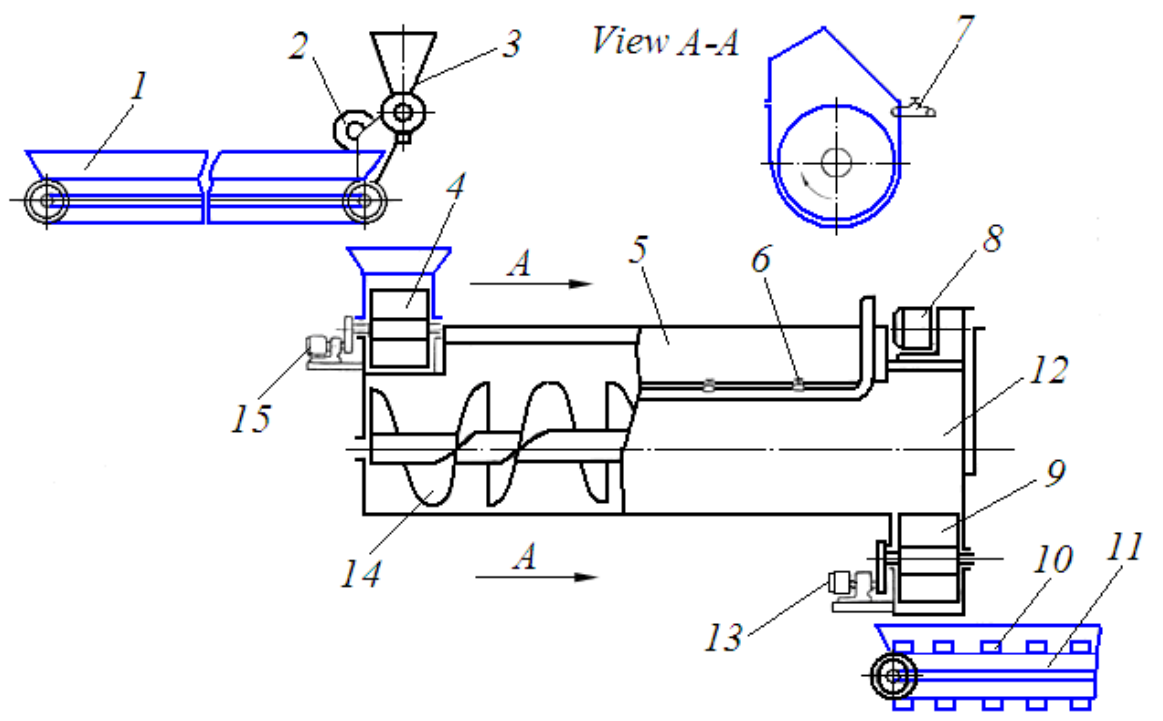

Fig. 1. Scheme of the experimental installation: 1 - feed conveyor; 2, 8, 13, 15-gear motors: 4, 9 are loading and unloading sluice gates; 5 is cover; 6 is distribution steam line; 7 is steam distributor; 10 is sample cell; 11 is belt discharge conveyor; 12 is housing; 14 is two-way screw with intermittent turns

After installing the discharge conveyor, samples are taken from each cell following the accepted method. 
Preliminary experimental studies were conducted to select a rational form of the mixing chamber [28-30]. At the same time, the mixer was equipped with three types of lids: flat, semicircular with a bulge facing outward, and in the form of a triangular box.

The analysis of the design and technological scheme of the mixing chamber showed that the type of lids changes the shape of the mixing chamber and significantly affects the quality of mixing.

In mixers with different types of lids, the direction of movement of the feed mass in the mixing chamber after being thrown up by the working body (screw) and interacting with the lid is different [33].

As mentioned above, the reflecting surface is the face located above the feed particle release zone in this cover. The angle of inclination of this face relative to the horizon determines the amount of feed reflected in the zone that does not coincide with the discharge zone and, in turn, the quality of mixing.

In this regard, to determine the optimal angle of inclination of the reflecting plane of this cover, we consider three characteristic directions of movement of the reflected feed particles in the free space above the screw.

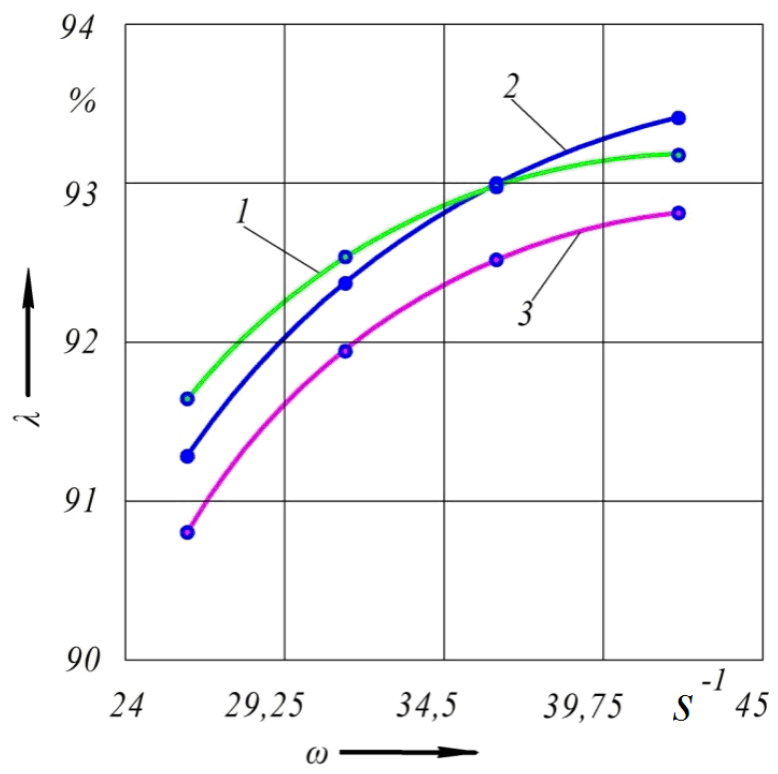

Fig. 5. The dependence of the mixing quality of the components on the angle of inclination of the reflecting cover and the speed of rotation of the screw; 1-at $\alpha=31^{\circ} 2$-at $\alpha=38^{\circ} 3$-at $\alpha=24^{\circ}$

To determine the quality of mixing that meets the zootechnical requirements, experiments were carried out at different second feeds of feed components. The results of the experiments are shown in Figure 6 . The figure shows that the mixer provides the necessary mixing quality at a capacity of up to $23 \mathrm{t} / \mathrm{h}$ for mixing crushed beets and mixed feed and up to $19 \mathrm{t} / \mathrm{h}$ - for green mass with mixed feed. At the same time, the maximum mixing quality is achieved - up to $93 \%$ with a mixer capacity of $15 \mathrm{t} / \mathrm{h}$ [22]. 


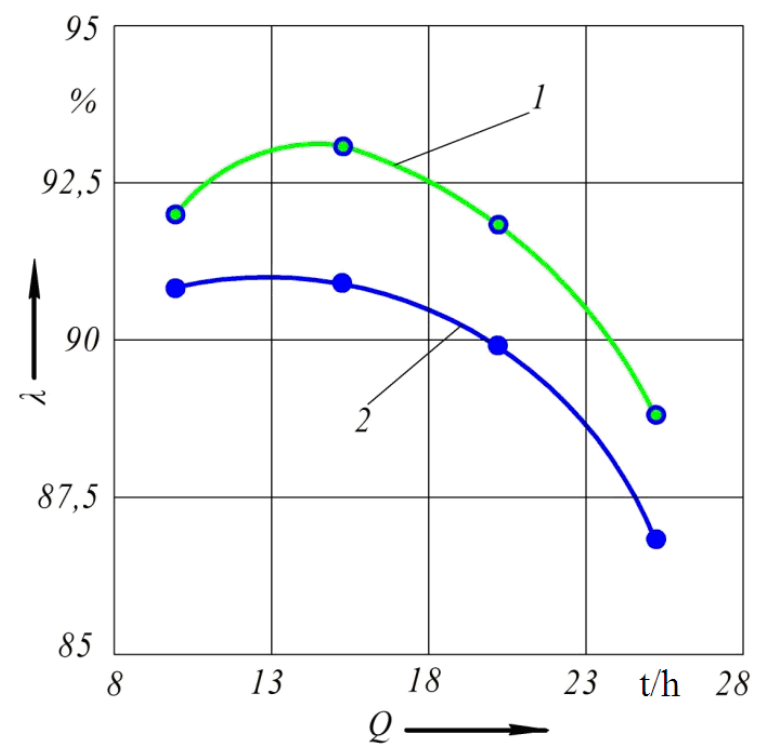

Fig. 6. Dependence of the mixing quality of the components on the mixer performance at $L=4 \mathrm{~m} ; \alpha=31^{\circ}$ $\omega=36.61 \mathrm{~s}^{-1}: 1$ is beet-mixed feed, 2 is green mass-mixed feed

\section{Conclusions}

1. The necessity of using the design of the mixer cover in the form of a three-sided box, which excludes additional resistance to the rotation of the screw due to the impact of the feed masses reflected from the cover, is justified. The use of a lid in the form of a three-sided box improves the mixing quality by $4-5 \%$ and reaches $93 \%$ or more at a capacity of $15 \mathrm{t} / \mathrm{h}$.

2. The result of experimental and theoretical studies found that the optimum tilt angle of the reflecting plane of the camera cover mix is $31-35^{\circ}$ when the diameter of the screw 400 $\mathrm{mm}$, the height of the reflecting plane of the axis of the screw $350 \mathrm{~mm}$ and speed $36,61 \mathrm{~s}^{-1}$.

3. According to the study of the mixer is determined by the following indicators: productivity, ensure the quality of mixing more than $90 \%$ when the mixed green mass of silage with forage $-19 \mathrm{t} / \mathrm{h}$, shredded fodder roots of forage $-23 \mathrm{t} / \mathrm{h}$, the frequency of rotation of the screw $-36,61^{-1}$.

\section{References}

1. Mamatov, F.M., Eshdavlatov, E., Suyunov, A. The Shape of the Mixing Chamber of the Continuous Mixer, Jour of Adv Research in Dynamical and Control Systems, Vol. 12, 07-Special Issue, (2020). DOI: 10.5373/JARDCS/V12SP7/20202318 ISSN 1943$023 \mathrm{X}$.

2. Mamatov, F., Ergashev, I., Ochilov, S., Pardaev, X. Traction Resistance of Soil Submersibility Type "Paraplau" // Jour of Adv Research in Dynamical \& Control Systems, Vol.12, 07-Special Issue, (2020). DOI: 10.5373/JARDCS/V12SP7/20202336 ISSN1943-023X.

3. Aldoshin, N., Mamatov, F., Ismailov, I., Ergashov, G. Development of combined tillage tool for melon cultivation // 19th international scientific conference engineering for rural development Proceedings, Jelgava, 19, (2020)

4. Umurzakov, U., Mirzaev, B., Mamatov, F., Ravshanov, H., Kurbonov, S. A rationale of broach-plow's parameters of the ridge-stepped ploughing of slopes, XII International 
Scientific Conference on Agricultural Machinery Industry IOP Conf. Series: Earth and Environmental Science 403(2019) 012163 IOP Publishing doi:10.1088/17551315/403/1/012163.

5. Mirzaev, B., Mamatov, F., Chuyanov, D., Ravshanov, X., Shodmonov, G., Tavashov, $\mathrm{R}$ and Fayzullayev, $\mathrm{X}$. Combined machine for preparing soil for cropping of melons and gourds, XII International Scientific Conference on Agricultural Machinery Industry. doi.org/10.1088/1755-1315/403/1/012158.

6. Mirzaev, B., Mamatov, F., Ergashev, I., Ravshanov, H., Mirzaxodjaev, Sh., Kurbanov, Sh., Kodirov, U and Ergashev, G. Effect of fragmentation and pacing at spot ploughing on dry soils, E3S Web of Conferences 97. doi.org/10.1051/e3sconf/201913501065.

7. Mamatov, F., Mirzaev, B., Shoumarova, M., Berdimuratov, P., Khodzhaev, D. Comb former parameters for a cotton seeder, International Journal of Engineering and Advanced Technology (IJEAT) 9

8. Mamatov, F., Mirzaev, B., Batirov, Z., Toshtemirov, S., Tursunov, O., Bobojonov, L. Justification of machine parameters for ridge forming with simultaneous application of fertilizers, IOP Conf. Series: Materials Science and Engineering 883(2020)

9. Mirzaev, B., Mamatov, F., Avazov, I., Mardonov, S. Technologies and technical means for anti-erosion differentiated soil treatment system, E3S Web of Conferences. doi.org/10.1051/e3sconf/20199705036.

10. Aldoshin, N., Didmanidze, O., Mirzayev, B., Mamatov, F. Harvesting of mixed crops by axial rotary combines // Proceeding of $7^{\text {th }}$ International Conference on Trends in Agricultural Engineering 2019. $17^{\text {th }}-20^{\text {th }}$ Prague, Czech Republic, (2019)

11. Mirzaev, B., Mamatov, F., Aldoshin, N and Amonov, M. Anti-erosion two-stage tillage by ripper, Proceeding of 7 th International Conference on Trends in Agricultural Engineering 17th-20th. Prague, Czech Republic. pp. 391-396, (2019)

12. Mirzaev, B., Mamatov, F., Ergashev, I., Islomov, Yo., Toshtemirov, B., Tursunov O. Restoring degraded rangelands in Uzbekistan // Procedia Environmental Science. № 6. - pp 395-404. (2019).

13. Uzakov, Z.U., Mamatov, F.M., Begulov, O. Implementation of object-oriented Programming technology in the one-dimensional oil displacement problem // International Conference on information Science and Communications Technologies: ICISCT 2019/0012008. Tashkent, Uzbekistan. INSPEC Accession Number: 19412491. DOI: $10.1109 /$ ICISCT47635.2019.9012008.

14. Mamatov, F., Mirzaev, B., Berdimuratov, P., Turkmenov, Kh., Muratov, L., Eshchanova, G. The stability stroke of cotton seeder moulder, IOP Conf. Series: Materials Science and Engineering 883 (2020) 012145 IOP Publishing. doi:10.1088/1757-899X/883/1/012145.

15. Mamatov, F., Mirzaev, B., Tursunov, O. A Justification of Broach-Plow's Parameters of the Ridge-Stepped Ploughing // E3S Web of Conferences 97, 05035 (2019). doi.org/10.1051/e3sconf/20199705035.

16. Ahmedov, B.J., Mirzaev, B.S.,Mamatov, F.M., Khodzhaev, D.A., Julliev, M.K. Integrating of gis and gps for ionospheric perturbations in d- And f-layers using vlf receiver // InterCarto, InterGIS 26, - c. 547-560. DOI: 10.35595/2414-9179-2020-1-26547-560.

17. Mamatov, F., Mirzaev, B., Tursunov, O., Ochilov, S and Chorieva, D. Relief, physicomechanical and technological properties of soil in the cotton growing area // ICECAE 2020. IOP Conf. Series: Earth and Environmental Science 614(2020) 012169. IOP Publishing. doi:10.1088/1755-1315/614/1/012169.

18. Shamsutdinov, Z., Ubaydullaev, Sh., Shamsutdinov, N., Mirzaev, B., Mamatov, F., and Chorshabiyev, N. The concept of the phytogenic field: theory, research experience and practical significance // ICECAE 2020. IOP Conf. Series: Earth and Environmental 
Science 614(2020) 012164. IOP Publishing. doi:10.1088/1755-1315/614/1/012164.

19. Umurzakov, U., Mamatov, F., Aldoshin, N., and Mirzaev, B. Exploration of tillage technologies in the Republic of Uzbekistan // ICECAE 2020 IOP Conf. Series: Earth and Environmental Science 614(2020) 012168. IOP Publishing. doi:10.1088/17551315/614/1/012168.

20. Mamatov, F., Aldoshin, N., Mirzaev, B., Ravshanov, H., Kurbanov, Sh and Rashidov, N. Development of a frontal plow for smooth, furless plowing with cutoffs // IPICSE 2020. IOP Conf. Series: Materials Science and Engineering 1030 (2021) 012135 IOP Publishing. doi:10.1088/1757-899X/1030/1/012135.

21. Mamatov, F., Mirzaev, B., Mirzahodzhaev, Sh., Uzakov, Z and Choriyeva, D. Development of a front plow with active and passive working bodies // IPICSE 2020. IOP Conf. Series: Materials Science and Engineering 1030 (2021) 012164. IOP Publishing. doi:10.1088/1757-899X/1030/1/012164.

22. Mamato, F.M., Eshdavlatov, E., Suyuno, A. Continuous Feed Mixer Performance //Journal of Advanced Research in Dynamical and Control Systems (JARDCS). Volume-12, 07-Spesia1 Issue, (2020). DOI: 10.5373/JARDCS/V12SP7/20202343. ISSN 1943-023X.

23. Mamatov, F., Ergashev, I., Mirzaev, B., Pardaev, X, Chorieva, D. Research of the Penetration Process of the Frontal Plow // 2nd Bukittinggi International Conference on Education (BICED) (2020). Journal of Physics: Conference Series 1779 (2021) 012002. IOP Publishing. doi:10.1088/1742-6596/1779/1/012002.

24. [24]Raskatova E.A. Issledovanie processa obrazovanija sypuchih smesej v kormoprigotovlenii i ego mehanizacija. - Avtoref. diss. na soiskanie uchenoj stepeni kand. tehn. nauk. - M.: (19560.

25. Klychev E.M. Issledovanie processa smeshivanija sypuchih kormov $\mathrm{v}$ psevdoozhizhennom sloe. - Avtoref. diss. na soiskanie uchenoj stepeni kand. tehn. nauk. - M., (1970).

26. Zhevlakov P.K. Issledovanie processov smeshivanija kormov. - Avtoref. diss. na soiskanie uchenoj stepeni kand. tehn. nauk. - L., (1958).

27. Karnauhov I.E. Mehanika unificirovannogo agregata dlja prigotovlenija kormovyh smesej. - V kn.: Tezisy dokladov Vsesojuznoj nauchno-tehnicheskoj konferencii VASHNIL. Melitopol', (1989)

28. Tregub L.I., Jeshdavlatov Je.U., Pravatov N.M. Smesitel'. A.s. №1465016, (1988).

29. Jeshdavlatov Je.U., Hamroev O.Zh. Optimal'nyj ugol naklona otrazhajushhej ploskosti kryshki smesitelja. Zhurnal. Nauka, tehnika i obrazovanie. № 6 (24) pp.37-39. Moskva (2016).

30. Jeshdavlatov Je.U., Jeshdavlatov A.Je. Vlijanie formy kamery smeshivanija na tehnologicheskij process. Zhurnal. Nauka, tehnika i obrazovanie. № 6 (24) pp.39-41. Moskva (2016).

31. Jeshdavlatov Je. U., Alikulov S. R. Opredelenie osevoj skorosti kormovoj massy v smesitele nepreryvnogo dejstvija. Zhurnal. Nauka, tehnika i obrazovanie. № 7 (225) pp.43-46. Moskva (2016).

32. Jeshdavlatov Je.U., Jeshdavlatov A.Je., Sujunov A.A. Raschet rashoda vodjanogo para i vybor ustrojstva podachi v kameru smeshivanija. Molodjozh' i sistemnaja modernizacija strany. Sbornik nauchnyh statej 2-j Mezhdunarodnoj nauchnoj konferencii studentov i molodyh uchenyh. 22-23 maja 2018 goda, v 4-h tomah, Tom-4, Jugo-Zap.gos.un-t., ZAO “Universitetskaja kniga”, pp.238-242. Kursk, (2018)

33. Je.Jeshdavlatov, A.Jeshdavlatov, A.Sujunov. Analiz formy kamery smeshivanija smesitelej nepreryvnogo dejstvija. Zhurnal: Nauka, tehnika i obrazovanie. № 4 (57) pp.36-40. Moskva (2019). 